\title{
Current prevalence, characteristics, and comorbidities of patients with COVID-19 in Indonesia
}

\author{
Dionita Rani Karyono, ${ }^{1}$ Anggi Lukman Wicaksana, ${ }^{2,3^{*}}$
}

${ }^{1}$ Unit for Collaboration, Alumni and Community Service, Faculty of Medicine, Public Health, and Nursing, Universitas Gadjah Mada, Yogyakarta, Indonesia.

${ }^{2}$ Department of Medical Surgical Nursing, Faculty of Medicine, Public Health, and Nursing, Universitas Gadjah Mada, Yogyakarta, Indonesia.

${ }^{3}$ The Sleman Health and Demographic Surveillance System (HDSS), Faculty of Medicine, Public Health, and Nursing, Universitas Gadjah Mada, Yogyakarta, Indonesia

KEYWORDS COVID-19

Characteristics Comorbidity Indonesia

Pandemic

Prevalence
ABSTRACT Indonesia is currently fighting against a novel coronavirus disease, known as COVID-19. Current information of COVID-19 is crucial for healthcare providers. This study aimed to explore the current prevalence, characteristics, and comorbidities of patients with COVID-19 in Indonesia. We obtained data of the confirmed cases of COVID-19, characteristics and comorbidities from the official website of Indonesia COVID-19 Task Force. The data were extracted, explored and discussed to respond to the research aims. Up to June 3rd, 2020, it was reported there were 28,233 confirmed cases of COVID-19 in Indonesia. The current prevalence of COVID-19 case was $0.11 \%$ ond transmission was distributed to all provinces in Indonesia. Almost one-third of the COVID-19 infections were in the age group of 31-45 years (29.3\%) but the highest mortality rate occurred in elderly people $(17.68 \%)$. Overall, males slightly dominated and contributed only $6.84 \%$ to the mortality rate. Cough (76.2\%), history of fever (50.4\%), and current fever (47.1\%) were the most common symptoms among the patients with COVID-19. For comorbidities, patients with COVID-19 had higher numbers of hypertension (52.1\%), diabetes (33.6\%), and other cardiovascular diseases (20.9\%). Those three comorbidities led the greater proportion of deaths among other comorbidities. The COVID-19 pandemic is still a new challenge for Indonesia.

(c) The Journal 2020. This article is distributed under a Creative Commons Attribution-ShareAlike 4.0 International license.

\section{Introduction}

Chinese authorities recognized the novel type of Severe Acute Respiratory Syndrome, Coronavirus Disease 2019 (SARS-CoV-2 or COVID-19) from a group of pneumonia cases in Wuhan City, Hubei Province, China, on January $7^{\text {th }}, 2020$. This COVID-19 is a new strain of coronavirus that infects humans and mostly causes respiratory problems or sudden deaths. On January $30^{\text {th }}, 2020$, the Director General of the World Health Organization (WHO) announced the COVID-19 outbreak as a public health emergency of international concern (PHEIC), with transitory suggestions given for all nations. ${ }^{1}$ On February $28^{\text {th }}$,

\footnotetext{
*Correspondence: anggi.I.wicaksana@ugm.ac.id

Department of Medical Surgical Nursing, Faculty of Medicine, Public Health, and Nursing, Universitas Gadjah Mada, Yogyakarta, Indonesia
}

2020, the WHO raised the hazard evaluation for COVID-19 from "high" to "very high" status. Then, on March $11^{\text {th }}, 2020$, COVID-19 was declared a pandemic. $^{2}$

In Indonesia, on April $13^{\text {th }}, 2020$, the President announced that the COVID-19 pandemic was a non-natural national disaster and needed urgent response. The Ministry of Health of Indonesia voted unanimously to establish the Indonesian COVID-19 Task Force as a national response for the COVID-19 outbreak. Confirmed and suspected cases have been reported from all regions in Indonesia, starting from the day of the first identified COVID-19 case and continuing to the current date. ${ }^{3}$ The updated data and COVID-19 situation assessments are distributed through the official COVID-19 Task Force website, mass media and government institutions. On the 
national level, the Ministry of Health of Indonesia has published national guidelines to control and eliminate the COVID-19 outbreak. ${ }^{4}$ All areas in Indonesia are following the COVID-19 protocol and apply hand hygiene, physical distancing, using a mask, lockdown, and some provinces instituted home confinement. ${ }^{5}$ The COVID-19 situation is daily updated by the Indonesian authorities. To date, there is a fluctuating trend about the COVID-19 cases in Indonesia but most of the COVID-19 cases are indicating an increasing trend. This trend of COVID-19 cases results in the increased numbers of deaths. ${ }^{3}$ All healthcare workers need to be aware of the current situation of COVID-19 cases in Indonesia. Accordingly, this study aimed to identify the current prevalence, characteristics and comorbidities of confirmed COVID-19 cases in Indonesia.

\section{Method}

This study used a narrative and explorative approach to identify the current prevalence, characteristics and comorbidities among patients with COVID-19 in Indonesia.

\subsection{Data sources}

Researchers extracted information from the dataset of patients with COVID-19 on the website of the Indonesian COVID-19 Task Force, Ministry of Health of Indonesia (https://covid19.go.id/peta-sebaran) until June 3th, 2020. It is an open-access dataset about the daily numbers and updates of clinical information related to COVID-19 in Indonesia. ${ }^{3}$

\subsection{Variable definition}

This study focused on discussing about the prevalence, characteristics and comorbidities among patients with COVID-19 in Indonesia. The COVID-19 cases are defined as cases of COVID-19 infection confirmed through positive result of polymerase chain reaction test. ${ }^{4}$ The prevalence is the recent number of confirmed COVID-19 cases that were reported in the Ministry of Health of Indonesia databases. Demography characteristics in this study are referring to the reported dataset regarding the age, gender, and symptoms of the confirmed patients with COVID-19. The comorbidities refer to present or previous diseases that are simultaneously present among the confirmed patients with COVID-19. The reported comorbidities among patients with COVID-19 were hypertension, diabetes, cardiovascular diseases, chronic obstructive pulmonary diseases, other respiratory problems, kidney diseases, asthma, cancer, tuberculosis, liver diseases and immune related diseases.

\subsection{Statistical analysis}

We applied descriptive statistics using a Microsoft Excel spreadsheet to extract and present the dataset into three components: the prevalence, characteristics, and comorbidities among patients with COVID-19 in Indonesia. The data were presented in numbers and proportion. The detailed datasets of patients who were recovered and the numbers of deaths were also reported.

\section{Result}

\subsection{The prevalence of COVID-19}

The confirmed cases of COVID-19 as of June $3^{\text {rd }}$, 2020 were reported as 28,233 positive cases. The total population in Indonesia is $255,182,144^{4}$ so the current prevalence of COVID-19 in Indonesia was $0.11 \%$. The COVID-19 cases were spread across all 34 provinces in Indonesia and the detailed information about COVID-19 distribution is available in Figure 1. Jakarta, East Java, and West Java have the most cases of COVID-19 in Indonesia.

The data in the Indonesian COVID-19 Task Force, from the Ministry of Health of Indonesia are daily updated and displayed through the official website. Among the information in the dataset, there were 93.7\% ( $n=26,454)$ and 98.1\% $(n=27,696)$ of data by age and gender, respectively. Only $6 \%(n=1,694)$ and $2.3 \%(n=649)$ of available data were presented in the database of COVID-19 by symptoms and comorbidities, respectively.

\subsection{Characteristics of patients with COVID-19}

The detailed data of COVID-19 cases by age are available in Table 1 . The majority of COVID-19 cases occurred in the age group of $31-45$ years (29.3\%) and it was followed by the age group of $46-59$ years 


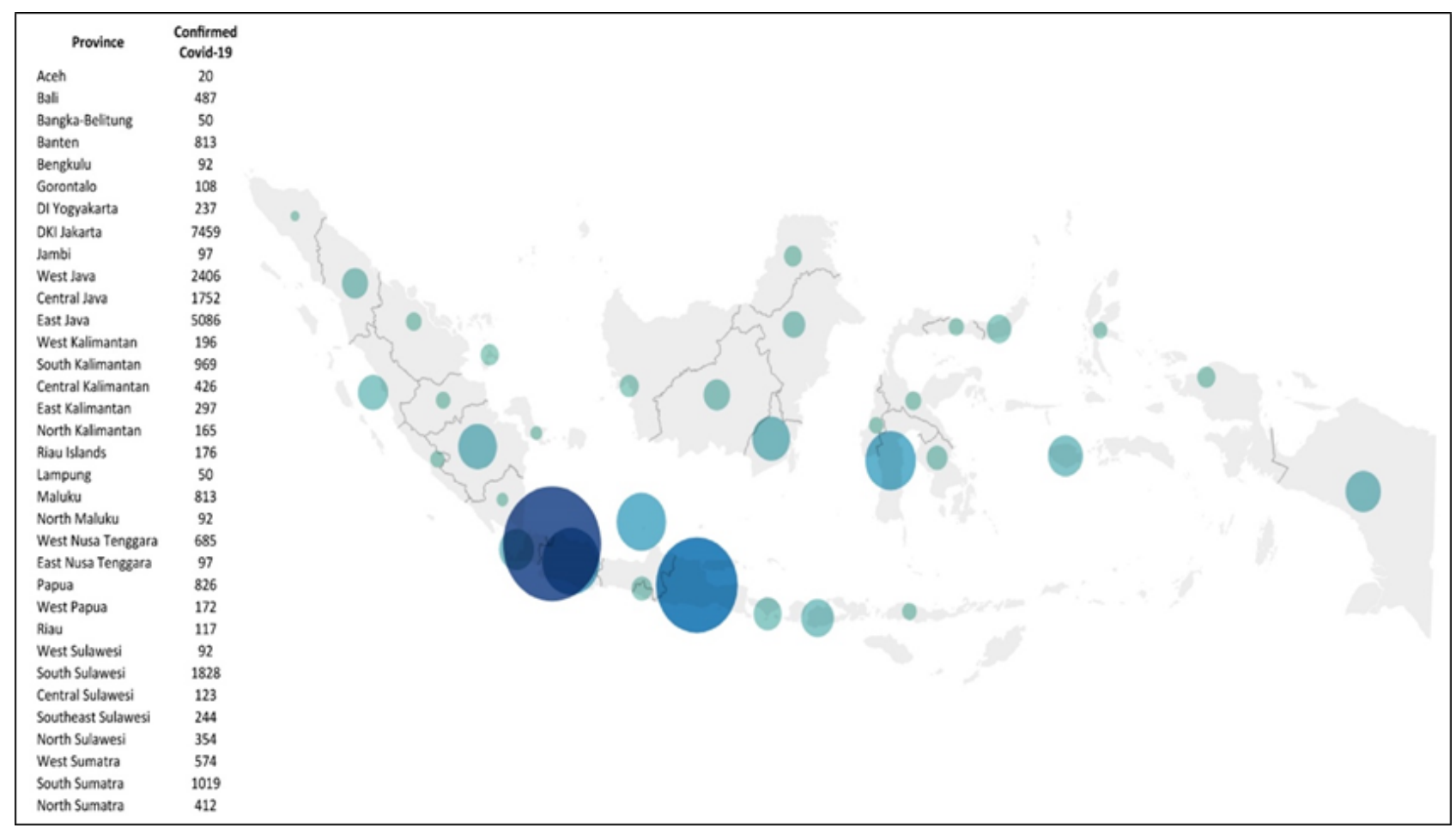

Figure 1. Current distribution of COVID-19 cases in Indonesia

Table 1. Total numbers of COVID-19 cases by age in Indonesia $(n=26,454)$

\begin{tabular}{lllllllll}
\hline $\begin{array}{l}\text { Age } \\
\text { (year) }\end{array}$ & $\begin{array}{l}\text { Proportion } \\
\text { (\%) }\end{array}$ & $\begin{array}{l}\text { Number of } \\
\text { cases }\end{array}$ & $\begin{array}{l}\text { Proportion } \\
\text { (\%) }\end{array}$ & Recovery & $\begin{array}{l}\text { Recovery } \\
\text { rate (\%) }\end{array}$ & $\begin{array}{l}\text { Proportion } \\
\text { (\%) }\end{array}$ & $\begin{array}{l}\text { Deaths } \\
\text { Mortality } \\
\text { rate (\%) }\end{array}$ \\
\hline $0-5$ & 2.3 & 608 & 1.5 & 118 & 19.42 & 0.9 & 14 & 2.35 \\
$6-17$ & 5.5 & 1,455 & 4.5 & 354 & 24.36 & 0.6 & 10 & 0.66 \\
$18-30$ & 20.7 & 5,476 & 20.7 & 1,630 & 29.77 & 3 & 48 & 0.87 \\
$31-45$ & 29.3 & 7,751 & 31.7 & 2,497 & 32.21 & 12 & 188 & 2.42 \\
$46-59$ & 27.3 & 7,222 & 27.2 & 2,142 & 29.66 & 39.9 & 635 & 8.79 \\
$\geq 60$ & 15 & 3,942 & 14.4 & 1,134 & 28.77 & 43.8 & 697 & 17.68 \\
\hline
\end{tabular}

Table 2. Total numbers of COVID-19 cases by gender in Indonesia $(n=27,696)$

\begin{tabular}{lllllllll}
\hline Gender & $\begin{array}{l}\text { Proportion } \\
(\%)\end{array}$ & $\begin{array}{l}\text { Number of } \\
\text { cases }\end{array}$ & $\begin{array}{l}\text { Proportion } \\
\text { (\%) }\end{array}$ & Recovery & $\begin{array}{l}\text { Recovery } \\
\text { rate (\%) }\end{array}$ & $\begin{array}{l}\text { Proportion } \\
(\%)\end{array}$ & Deaths & $\begin{array}{l}\text { Mortality } \\
\text { rate (\%) }\end{array}$ \\
\hline Males & 54.6 & 15,123 & 58 & 4,783 & 31.62 & 62.1 & 1,035 & 6.84 \\
Females & 45.4 & 12,574 & 42 & 3,463 & 27.54 & 37.9 & 631 & 5.01 \\
\hline
\end{tabular}

Note: $n$, number of COVID-19 cases.

(27.3\%). The recovery rate was dominated by the age group of 31-45 years (32.21\%) and it was followed by the adult groups. Additionally, the highest proportion of deaths was identified among the elderly (43.8\%). The mortality rate indicated a similar trend in which the elderly contributed to the highest rate (17.69\%).

In terms of gender, the COVID-19 virus infected more males $(54.6 \%, n=15,123)$ than females (Table 2). The males had a recovery rate of $31.62 \%$ and mortality rate of $6.84 \%$, relatively higher than females.

The most common symptoms among patients with COVID-19 in Indonesia were cough (76.2\%), history of fever $(50.4 \%)$, current fever $(47.1 \%)$, and shortness of breaths (41.6\%) (Figure 2). Most of the patients had complaints in the respiratory system. The rest of them had complaints in the musculoskeletal and gastrointestinal systems.

\subsection{The comorbidities among patients with COVID-19}




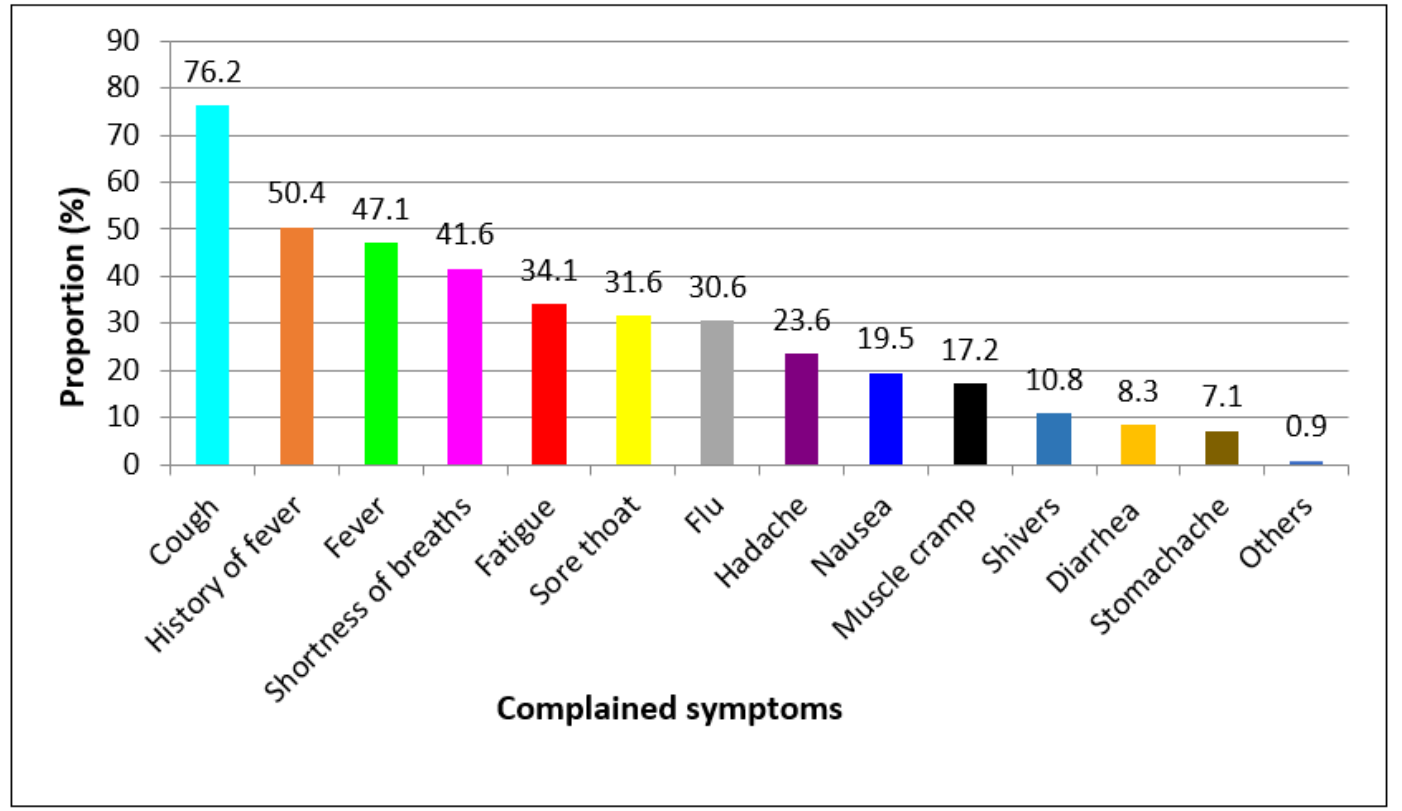

Figure 2. The proportion of COVID-19 cases by its symptoms $(n=1,694)$

Table 3. The comorbidities of COVID-19 in Indonesia $(n=649)$

\begin{tabular}{|c|c|c|c|c|c|c|c|c|}
\hline Comorbidity & $\begin{array}{l}\text { Proportion } \\
\text { (\%) }\end{array}$ & $\begin{array}{l}\text { Number of } \\
\text { cases }\end{array}$ & $\begin{array}{l}\text { HASQ } \\
\text { (\%) }\end{array}$ & $\begin{array}{l}\text { Number } \\
\text { of HASQ }\end{array}$ & $\begin{array}{l}\text { Recovery } \\
\text { (\%) }\end{array}$ & $\begin{array}{l}\text { Number of } \\
\text { recovery } \\
\text { patients }\end{array}$ & $\begin{array}{l}\text { Death } \\
\text { (\%) }\end{array}$ & $\begin{array}{l}\text { Number } \\
\text { of deaths }\end{array}$ \\
\hline Hypertension & 52.1 & 341 & 4.1 & 14 & 28.7 & 98 & 19.2 & 65 \\
\hline Diabetes mellitus & 33.6 & 220 & 2 & 4 & 16.3 & 36 & 15.3 & 33 \\
\hline $\begin{array}{l}\text { Cardiovascular } \\
\text { diseases }^{\text {a }}\end{array}$ & 20.9 & 137 & 1.8 & 2 & 8.9 & 12 & 10 & 13 \\
\hline $\begin{array}{l}\text { Chronic obstructive } \\
\text { pulmonary diseases }\end{array}$ & 15.1 & 99 & 0.3 & 1 & 11.1 & 11 & 3.7 & 5 \\
\hline $\begin{array}{l}\text { Other respiratory } \\
\text { problems }\end{array}$ & 9 & 60 & 0.9 & 1 & 5 & 3 & 3.2 & 2 \\
\hline Kidney diseases & 4.9 & 32 & 0 & 0 & 0.8 & 0 & 4.1 & 1 \\
\hline Asthma & 3.1 & 20 & 0.6 & 1 & 1.8 & 0 & 0.6 & 1 \\
\hline Cancer & 2.3 & 15 & 0.2 & 1 & 1.1 & 0 & 1.1 & 1 \\
\hline Tuberculosis & 1.8 & 12 & 0.3 & 1 & 1 & 0 & 0.3 & 1 \\
\hline Liver diseases & 1.2 & 8 & 0 & 0 & 0.9 & 0 & 0.3 & 1 \\
\hline $\begin{array}{l}\text { Immune related } \\
\text { diseases }\end{array}$ & 1.2 & 8 & 0 & 0 & 0.6 & 0 & 0.6 & 1 \\
\hline
\end{tabular}

Note: HASQ, hospital admission and self-quarantine; \%, percentage; a except for hypertension

The detailed data of comorbidities among patients with COVID-19 are available in Table 3. The top three comorbidities were hypertension (52.1\%), diabetes mellitus (33.6\%), and other cardiovascular diseases (20.9\%). The data of other cardiovascular diseases refer to a number of heart diseases, including heart attack, stroke, heart failure, and others, except for the hypertension. Patients with COVID-19 who have mild symptoms are not hospitalized, and they usually do self-quarantine or confinement at home.
The duration of hospitalization which is as long as self-quarantine is usually about 14 days. The rates for hospital admission and self-quarantine (HASQ) were varied in which hypertension, diabetes, and other cardiovascular diseases accounted for $4.1 \%$, $2 \%$, and $1.8 \%$, respectively. Among the patients with COVID-19, the three comorbidities: hypertension, diabetes, and other cardiovascular diseases were leading in terms of the numbers of treated patients, recoveries, and deaths, compared to other 
comorbidities.

\section{Discussion}

This study provides information on current prevalence, characteristics, and comorbidities of patients with COVID-19 in Indonesia. The prevalence of COVID-19 in Indonesia was relatively lower than cases in Belgium, UK, Spain, USA, Italy, and France and it has spread out to all provinces. The finding of the mortality rate of patients with COVID-19 in Indonesia was similar with the estimated United Nations report, with 10 deaths per 1,000 infections. Globally, mortality rate was about 70 deaths per 1,000 infections $^{6}$ which was relatively higher than the mortality rate in Indonesia.

The DKI Jakarta and East Java provinces were the epicenter of COVID-19 cases between March and June 2020 in Indonesia. In addition, the first case of COVID-19 in Indonesia was found in DKI Jakarta. The higher number of COVID-19 cases was related to the high mobility of the population. A previous survey in 2019 indicated that 1.2 million people visited DKI Jakarta everyday. ${ }^{7}$ Jakarta, the capital city of Indonesia, is located in the DKI Jakarta province, and is the main hub of the nation's economy. In Jakarta city, population density is very high (138 people in $\mathrm{km}^{2}$ ) and this allows the COVID-19 to spread more epicly. ${ }^{7,8}$ Meanwhile, on June 26th, 2020, the Indonesian COVID-19 Task Force announced that the East Java province had become the new epicenter of COVID-19 transmission. They also reported that the sudden outbreak of COVID-19 and its rapid spread in Surabaya could be due to the lack of awareness among residents of Surabaya concerning COVID-19 preventive protocols. ${ }^{9}$

Patients in the productive age (18-59 years old) have dominated the incidence of COVID-19 in Indonesia. Adult people are actively working and engaging in many daily activities. As a result, it was easy for them to be infected when they did not strictly adhere to the protocols of COVID-19 control. ${ }^{10} \mathrm{~A}$ previous study in China identified that COVID-19 mostly infected elderly people because they are lacking in their immune system as the result of the aging process. ${ }^{11}$ Furthermore, most elderly people had multi-morbidities that made them more vulnerable to the COVID-19 infection. ${ }^{11}$ The elderly have been identified as a high-risk group for COVID-19 infection. ${ }^{11}$ In Indonesia, the percentage of elderly patients with COVID-19 was 15\%, however, the mortality rate in older Indonesian people with COVID-19 was the highest compared to the other age groups. ${ }^{3}$ This finding was consistent with the previous research in the UK, which indicated the highest mortality rate occurred among persons with advanced age, with more than 200 patients on average. In comparison, the age group below 60 years old showed an average mortality rate that was less than 100 patients. ${ }^{12}$ Thus, elderly patients with COVID-19 should have priority in medical care due to their vulnerability state. ${ }^{13}$

We observed more cases of COVID-19 in Indonesia that were men than women. Several studies indicated similar findings in which more men were infected with COVID-19 than women. ${ }^{11,12,14,15}$ The men's mortality rate was slightly higher than for women. Women are known to be more resilient in terms of viral infection. This is associated with the $\mathrm{X}$ chromosome protection and estrogen hormones, which have an essential role in the adaptive immunity mechanisms. ${ }^{16}$ The $X$ chromosome involves several genes that are associated with the immunological process, such as multiple cytokine receptors, genes involved in T-cell and B-cell activities, and transcriptional and translational regulatory factors. ${ }^{16}$ In addition, women have more estrogen receptors which protect the body and assist the immune system, including T cells, B cells, macrophages, neutrophils, dendritic cells, and natural killer cells. ${ }^{16,17}$

Cough and (current or history of) fever were the most common complained symptoms among the confirmed cases of COVID-19. The finding was similar to earlier studies. ${ }^{11,18,19}$ Sharma et al. explained that symptoms of COVID-19 mostly began with dry cough, fever, fatigue and myalgia in the first four days. Then, dyspnea and purulent cough followed as the next naturally occurring symptoms until the $6^{\text {th }}$ day. ${ }^{20}$ When COVID-19 infects the body, the viruses can enter and destroy the apical side of lung epithelial cells in the alveolar space by attaching to the angiotensin converting enzyme (ACE-2). The ACE- 2 is commonly found in the apex of nasal, oral, nasopharyngeal membranes and oro-pharyngeal 
mucosal and alveolar epithelium, endothelial cells in heart, blood vessels, renal tubules, and small intestine enterocytes. ${ }^{21}$

In Indonesia, the highest comorbidity among patients with COVID-19 was hypertension and then it was gradually followed by diabetes, other cardiovascular diseases, and chronic obstructive pulmonary diseases (COPD). These phenomena were similar with the previous reports in China and the UK. ${ }^{12,22,23}$ Hypertension was identified as a predominant factor of COVID-19 infection. There were many assumptions that people with unstable blood pressure commonly had more renin angiotensin aldosterone system (RAAS) inhibitors such as the ACE-2 which are related to increased COVID-19 susceptibility. ${ }^{24,25}$ In several studies, COVID-19 patients with hypertension were associated with poor health outcomes, longer hospital stay, and ICU admission. Moreover, COVID-19 patients with hypertension had two times higher risk for death. Among other comorbidities, hypertension was recognized as the leading cause of death among patients with COVID-19. ${ }^{26}$

COVID-19 patients with diabetes rank as the second largest number of comorbidities. ${ }^{27-29}$ Diabetic patients are a high-risk group for COVID-19 infection..$^{29,30}$ The researchers have identified that poor glycemic control was related to the poor outcome of patients with severe COVID-19. ${ }^{27}$ Similar to hypertension, COVID-19 patients with diabetes had a higher risk of extended hospital stay and ICU admission. Roncon et al. reported patients with diabetes had almost three times higher risk for ICU admission (OR 2.79; 95\% Cl: 1.85-4.22) and death (OR 3.21; 95\% Cl: 1.82-5.64). ${ }^{27}$ These findings highlighted that diabetes is one of the high-risk factors for severe COVID-19 infection that needs more attention and medical care. ${ }^{30}$

In China and the UK, COPD commonly occurred among patients with COVID-19, just as in the findings in Indonesia. 12,23 In China, confirmed COVID-19 patients with COPD had a higher mortality rate. The majority of COVID-19 patients with COPD had various comorbidities, which may also be related to the higher mortality. ${ }^{31}$ In addition, respiratory failure in COVID-19 patients with severe COPD is the leading cause of death and it requires ICU intervention. To date, the specific mechanism of COPD that increases COVID-19 severity and mortality is unknown and further research is needed to identify the possible mechanisms linking COVID-19 with increased severity and higher risk of death. ${ }^{32}$

The limitations of this study were related to the number of prevalence, availability of dataset, and numbers of comorbidities among patients with COVID-19. The prevalence of COVID-19 cases in Indonesia is dynamic because the Indonesian authorities will daily update the case numbers. The current prevalence may potentially differ day by day according to the updated new cases. The reported characteristics in this study only focused on age, gender, and complained symptoms. This reporting was due to the availability of datasets that were published in the Indonesian COVID-19 Task Force's homepage. Accordingly, the reported numbers of comorbidities among patients with COVID-19 only represented the estimated numbers out of the total cases of COVID-19 due to the limited available data and the possibility of underreporting in some areas of Indonesia.

\section{Conclusion}

This report provided information about the current prevalence, characteristics, and comorbidities among patients with COVID-19 in Indonesia. The presented data indicated that the COVID-19 pandemic is a new challenge for this country. All healthcare providers could use this information to become better updated and more aware during the COVID-19 outbreak. In identifying the nation's greatest concerns, the mortality rate was higher among elderly patients with COVID-19 and COVID-19 patients with hypertension, diabetes, and other cardiovascular diseases.

\section{Conflict of interests}

The authors declare that there is no conflict of interest.

\section{References}

1. WHO. Coronavirus Update. 2020. [updates: March 11, 2020 cited June, 17 2020]. Available from: www.who.int 
2. WHO. COVID-19 Situation update for the WHO African Region: External Situation Report 4. 2020;1-7 (internet). [cited: June 18, 2020]. Available from: https://apps.who.int/iris/ bitstream/handle/10665/331587/SITREP_ COVID-19_WHOAFRO_20200325-eng.pdf

3. Indonesia's TaskForce for COVID-19. Peta Sebaran (internet). [cited: June 3, 2020]. Available from: https://covid19.go.id/petasebaran

4. Kemenkes RI. Pedoman Pencegahan dan Pengendalian Coronavirus Disease (COVID-19). Kemenkes RI. 2020;0-115.

5. Magista M, Hertanti NS. Buku Saku Desa Tangguh COVID-19. 2020. Universitas Gadjah Mada. Available from: https://tropmed.fk.ugm. ac.id/2020/04/14/buku-saku-desa-tangguhcovid-19-ver-1/

6. United Nation Geoscheme. COVID-19 Coronavirus Pandemic (internet). [update June 3 2020 cited June 3, 2020] Available from: https:// www.worldometers.info/coronavirus/?utm campaign=homeAdUOA?Si\#countries

7. Survei Komuter Jabodetabek. 2019 [Internet]. [Cited 19 July 2020]. Available from: $\quad$ https://databoks.katadata.co.id/ datapublish/2020/01/21/seberapa-padatpenduduk-dki-jakarta-2019.

8. Tosepu R, Gunawan J, Effendy DS, Ahmad LOAI, Lestari $\mathrm{H}$, Bahar $\mathrm{H}$, et al. Correlation between weather and Covid-19 pandemic in Jakarta, Indonesia. Sci Total Environ. 2020;725.

9. The Jakarta Post. Covid-19-transmission-ratesoars-surabaya-urged-to-restore-restrictions (internet). [cited June 15, 2020] Available from: https://www.thejakartapost.com/ news/2020/06/18/as-covid-19-transmissionrate-soars-surabaya-urged-to-restorerestrictions.html

10. Kraemer MUG, Yang $\mathrm{CH}$, Gutierrez B, $\mathrm{Wu} \mathrm{CH}$, Klein $B$, Pigott DM, et al. The effect of human mobility and control measures on the COVID-19 epidemic in China. Science. 2020;368(6490):493-7.

11. Niu S, Tian S, Lou J, Kang $X$, Zhang L, Lian $H$, et al. Clinical characteristics of older patients infected with COVID-19: a descriptive study. Arch Gerontol Geriatr. 2020;89:104058.

12. Docherty $A B$, Harrison EM, Green CA, Hardwick
HE, Pius R, Norman L, et al. Features of 16,749 hospitalised UK patients with COVID-19 using the ISARIC WHO clinical characterisation protocol. medRxiv. 2020;2.

13. Chen T, Wu D, Chen H, Yan W, Yang D, Chen G, et al. Clinical characteristics of 113 deceased patients with Coronavirus Disease 2019: retrospective study. BMJ. 2020;368.

14. Huang $C$, Wang $Y$, Li $X$, Ren L, Zhao J, Hu Y, et al. Clinical features of patients infected with 2019 novel coronavirus in Wuhan, China. Lancet. 2020;395(10223):497-506.

15. Chen N, Zhou M, Dong X, Qu J, Gong F, Han Y, et al. Epidemiological and clinical characteristics of 99 cases of 2019 novel coronavirus pneumonia in Wuhan, China: a descriptive study. Lancet. 2020;395(10223):507-13.

16. Giefing-Kröll C, Berger P, Lepperdinger G, Grubeck-Loebenstein B. How sex and age affect immune responses, susceptibility to infections, and response to vaccination. Aging Cell. 2015;14(3):309-21.

17. Channappanavar R, Fett C, Mack M, Eyck P, Meyerholz D, Perlman S. Sex-based differences in susceptibility to Severe Acute Respiratory Syndrome Coronavirus infection. J Immunol. 2017;198:4046-53.

18. Li R, Tian J, Yang F, Lv L, Yu J, Sun G, et al. Clinical characteristics of 225 patients with COVID-19 in a tertiary hospital near Wuhan, China. J Clin Virol. 2020;127:18-20.

19. Lv Z, Cheng S, Le J, Huang J, Feng L, Zhang B, et al. Clinical characteristics and co-infections of 354 hospitalized patients with COVID-19 in Wuhan, China: a retrospective cohort study. Microbes Infect. 2020;22(4-5):195-9.

20. Sharma R, Agarwal M, Gupta M, Somendra S, Saxena SK. Clinical characteristics and differential clinical diagnosis of novel Coronavirus Disease 2019 (COVID-19). Coronavirus Diseases 2019. 2020;2019:55-70.

21. Dhochak N, Singhal T, Kabra SK, Lodha R. Pathophysiology of COVID-19: why children fare better than adults? Indian J Pediatr. 2020;87:537-46.

22. Guan WJ, Liang WH, Zhao Y, Liang HR, Chen ZS, Li YM, et al. Comorbidity and its impact on 1,590 
patients with Covid-19 in China: a nationwide analysis. Eur Respir J. 2020;55(5).

23. Yang J, Zheng Y, Gou X, Pu K, Chen Z, Guo Q, et al. Prevalence of comorbidities and its effects in coronavirus disease 2019 patients: a systematic review and meta-analysis. Int J Infect Dis. 2020;94:91-5.

24. Kulkarni S, Jenner BL, Wilkinson I. COVID-19 and hypertension. JRAAS - J Renin-AngiotensinAldosterone Syst. 2020;21(2).

25. Cancarevic I, Malik BH. SARS-CoV-2 (COVID 19) Infection in hypertensive patients and in patients with cardiac disease. Cureus. 2020;2(6):e8557.

26. Huang S, Wang J, Liu F, Liu J, Cao G, Yang C, et al. COVID-19 patients with hypertension have more severe disease: a multicenter retrospective observational study. Hypertens Res. 2020.

27. Roncon L, Zuin M, Rigatelli G, Zuliani G. Diabetic patients with COVID-19 infection are at higher risk of ICU admission and poor short-term outcome. J Clin Viro. 2020;127.

28. Hussain A, Bhowmik B, do Vale Moreira NC. COVID-19 and diabetes: knowledge in progress.
Diabetes Res Clin Pract. 2020;162:108142.

29. Wicaksana AL, Hertanti NS, Ferdiana A, Pramono RB. Diabetes management and specific considerations for patients with diabetes during coronavirus diseases pandemic: A scoping review. Diabetes Metab Syndr. 2020;14(5):11091120.

30. Hill MA, Mantzoros C, Sowers JR. Commentary: COVID-19 in patients with diabetes. Metab. 2020;107:154217.

31. Grasselli G, Ospedale G, Policlinico M, Pesenti A, Ospedale $G$, Policlinico $M$, et al. Critical care utilization for the COVID-19 outbreak in Lombardy, Italy: early experience and forecast during an emergency response. 2020;323(16):1545-6.

32. Alqahtani JS, Oyelade T, Aldhahir AM, Alghamdi $S M$, Almehmadi $M$, Alqahtani $A S$, et al. Prevalence, severity and mortality associated with COPD and smoking in patients with COVID-19: a rapid systematic review and metaanalysis. PLoS One. 2020;15(5):1-13. 